\title{
Managerial communication and its changes in the global intercultural business world
}

\author{
Marcel Pikhart ${ }^{1 \mathrm{a}}$ \\ ${ }^{1}$ University of Hradec Kralove, Faculty of Information Technology and Management, Department of \\ Applied Linguistics, Hradec Kralove, Czech Republic
}

\begin{abstract}
The current business world is experiencing significant changes in the way people communicate in the global intercultural environment. The presented paper summarizes the most common trends and attempts to find invariants of this communication so that it could possibly facilitate business communication in the global world leading to increased efficiency and thus profitability. The communication tools used in this communication have seen unprecedented changes which influence not only the means of communication but also its contents and pace at which the information is transferred. To understand these phenomena will help us to enhance the business communication but also to eliminate misunderstandings which can potentially create serious problems.

Keywords: Managerial communication; business world; communication tools
\end{abstract}

\section{Introduction}

The current business world is experiencing significant changes in the way people communicate in the global intercultural environment, and thus, the author attempts to focus on these changes inasmuch they can influence business communication and company profitability. The presented paper summarizes the most common trends of business intercultural communication and tries to find invariants of this communication so that it could possibly facilitate business processes in the global world leading to increased efficiency and therefore even profitability.

\subsection{Literature review}

The topic of global changes in business and communication has already got enough attention from the scholars [9]. There has also been a lot of research into business communication $[4,7,12,18]$, into global business communication $[1,11,18]$ and intercultural communication $[2,5,8]$ in the last two decades due to the increased

\footnotetext{
${ }^{a}$ Corresponding author: author@e-mail.org
} 
interconnections among companies since the beginning of the new millennium. The introduction of the Internet as the new medium of communication has changed the way the information is transferred and the way the companies communicate so that the need for the research from linguistics [10,15, 19], sociopragmatics [6], managerial and communication studies was very urgent. However, we still lack a combination of these approaches which would look for synergy of these analyses. We claim that it is not very useful to describe business communication from a merely linguistics point of view, and similarly, the pure managerial approach to business communication is not sufficient either to explain properly the trends and the consequences. Therefore, we are trying to find a symbiosis of these approaches [14].

\subsection{Current trends in business communication}

The communication tools used in business communication have seen unprecedented changes which influence not only the means of communication but also its contents and pace at which the information is transferred $[3,16]$. To understand these phenomena will help us to enhance the business communication but also to eliminate misunderstandings which can potentially create serious problems in the business market [13, 17].

The modern communication tools are widely used not only in everyday communication but also in business communication, and more and more people from various cultural contexts use these tools to exchange information. First, it is the modern communication tools, and second, intercultural business environment which create the background and platform of our communication. These two phenomena significantly influence the nature of our business communication and the paper tries to find how they interfere with each other.

There are a few new issues emerging from the global nature of current business communication as described by Hua [7]. She talks about the difficulties when looking for a common language, problems with inadequate translations into the subsidiary language, difficulties with spoken language and its varieties, centralisation of the power to the hands of a few people who lead the company through the official language, and the people lacking the language and communication skills may feel isolated. It is possible to spot these trends and therefore our research tries to find out if these issues are still under way.

\section{Research}

The presented study is significant for all companies as basically all of them do some international business, i.e., they must communicate in the global business environment when using modern communication technologies. However, as the research shows, the managers are not aware of potential communication problems arising from the situation. The aim of the research was to find out what the current trends of business communication are and how these trends can be described so that they can be better understood. The research also looked into the connection between globalization and technical changes in communication in intercultural management.

\subsection{Research methodology}

The methodology used in the research was observations and questionnaires, as the author has access to several Asian and European multinational corporations and small and medium enterprises as a consultant, therefore, the data collected are both quantitative and qualitative. The researched companies do business both in the European and the Asian 
markets in areas of insurance, banking but also industrial production and machinery. The top management is both European and Asian, and the employees are mostly European.

Several interviews were conducted with the top and middle management of these companies or the company owners as well, to evaluate and find out the level of awareness of the situation in the global market regarding the communication principles and standards. The data obtained were processed using standardised techniques of statistics and further used in implications and discussion part of the paper.

\subsection{Research results}

The research results led us to several findings which can prove useful not only for the academic world but also for the people who are responsible for communication strategies in the companies, i.e., the top management, middle management, sales people responsible for external communication, and HR employees who are responsible for internal communication setting.

The people responsible for intercultural business communication are usually not aware of the potential pitfalls and the results of the research can also bring important ideas for improvement of the communication strategies in the companies. Almost everyone has agreed that the quantity of transferred information has increased dramatically versus the quality of the information.

The language competencies of the middle and top management of these companies were on a good level or even very good levels, however, the intercultural communication competencies were somehow neglected. Just a few companies offered training of intercultural communication skills for the management. The business communication has changed radically as confirmed by the majority of respondents usually complaining about the unprecedented increase of the volume of information, the quantity versus the quality of information is perceived in a very negative way.

The virtual electronic communication, now dominating over traditional mail, has led to quantitatively unlimited stream of dozens to hundreds of emails a day, which causes significant problems in maintaining the communication in a manageable way. The significant part of information is lost during the process of the transfer of the information due to the improper use of the modern communication means. The majority of the researched managers would welcome the change if all the people involved in business communication would be aware of the current trends.

\section{Discussion}

The author tries to show that managerial training of intercultural communication abilities is a must for anyone who does international business and that is also the reason why the paper calls for this kind of training which should be implemented in the university curricula for the students who study business and economy, international trade and business related study programmes. The research results clearly show the urge of the current world to be able to communicate in the intercultural world efficiently and use modern communication tools so that they facilitate the communication and not blur the message which is intended to be transferred.

All the described changes also caused many organisational alterations leading to core business thinking, major use of outsourcing, increased specialization, and thus, increased cooperation in the form of joint ventures and global alliances. Communication therefore becomes the key topic as the pace of globalization is very fast and it supports making networks and cooperation with partners from various cultural backgrounds. 


\section{Conclusion and implications}

Communication plays a crucial part in modern business and is probably one of the most important issues when doing business globally. Neglecting the communication and its proper function would have fatal consequences which would inevitably lead to the loss of the market, current or potential. The presented study is significant for all companies as basically all of them do some international business, i.e., they must communicate in the global business environment using modern communication technologies. However, as the research shows, the managers are not aware of potential communication problems arising from the situation.

When predicting the future development, we have to take into account that multicultural and intercultural communication will take the lead in the global communication, Discourse and communication will create the space for competitiveness and innovativeness. The global companies are created as networks of people from multicultural environments and the top and middle management must be aware that there are specific competencies for them to manage these people. Intercultural competencies and the right solving of problems in this environment will be a must for anyone who wants to be successful in the global market. The role of trust will also be taken into account as it will be more and more important in managing people. Their involvement and engagement will be connected to the way the management communicates with them, and this communication will always be intercultural due to the nature of the current world.

\section{References}

1. M. J. Gannon, K. L. Newman. The Blackwell Handbook of Cross-cultural Management. Oxford: Blackwell Publishers Ltd, (2002)

2. A. Firth, The Lingua Franca Factor. Intercultural Pragmatics 6-2, 147-170, 1612295x/09/0006-0147, (2009)

3. T. L. Friedman, The World is Flat: A Brief History of the Twenty-First Century, (2007)

4. M. Geeritsen, C.Nickerton, BELF: Business English as a Lingua Franca. In The Handbook of English Discourse, (2009)

5. A.Holliday, M. Hyde, J. Kullman, Intercultural Communication. An Advanced Resource Book for Students, (2010)

6. J. House, Introduction: The Pragmatics of English as a Lingua Franca. Intercultural Pragmatics 6, 141-145, (2009)

7. Z. Hua, Exploring Intercultural Communication. Language in Action,(2014)

8. J. Jackson, Introducing Language and Intercultural Communication, (2014)

9. A. Koblizkova (Eds.), R. Kucha, H.Cudak, Intercultural Communication through International English. p. 101 - 115. In European ideas in the works of famous educationalists. Internationalization, globalization and their impact on education. Studia i Monografie nr. 41 (2013). Łódź, Społeczna Akademia Nauk, pp. 558, (2013).

10. W. P. Lehman, The role of Intercultural Studies in the Development of Linguistics. Intercultural Communication Studies XV: 3 (2006)

11. R. D. Lewis, When Cultures Collide: Leading Across Cultures, (1996)

12. L. Louhiana-Salmien, Business Communication. In The Handbook of English Discourse. Ed. Francesca Bargiela-Chiappini, (2009)

13. A. Luzio, Culture in Communication: Analyses of Intercultural Situations, (2001)

14. M. Pikhart, Interkulturní komunikace v globálním obchodě. Perspektivainterkulturního managementu, (2013)

15. I. Piller, Linguistics and Intercultural Communication. Language and Linguistics Compass 1/3 (2007) 208-226 (2007) 
16. L. A. Samovar, R. E. Porter, Communication Between Cultures, (2007)

17. H. Spencer-Oatey, Culturally Speaking. Culture, Communication and Politeness Theory, (2008)

18. P. Tan, R. Rudby, Language as Commodity. Global Structures, Local Marketplace. (2008)

19. H. G. Wolf, F. Polzenhagen, Intercultural Pragmatics 3-3 285-321, (2006). 